\title{
COMMUNICATION IN TIMES OF PANDEMIC, IMPACT IN ECUADORIAN EDUCATION
}

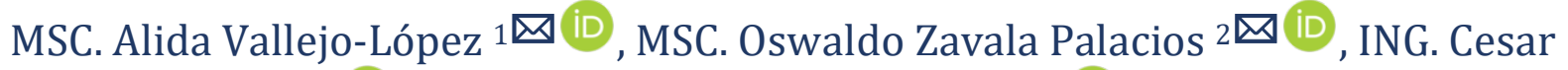

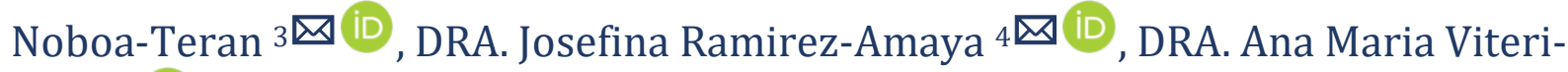
Rojas 5 iD

1, 2, 3, 4, 5 Universidad De Guayaquil, Guayaquil University, Faculty of Medical Sciences Guayaquil,

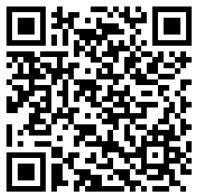
Ecuador

DOI: https://doi.org/10.29121/granthaalayah.v8.i9.2020.1586

Article Type: Research Article

Article Citation: Msc. Alida VallejoLópez, Msc. Oswaldo Zavala Palacios, Ing. Cesar Noboa-Teran, Dra. Josefina Ramirez-Amaya, and Dra. Ana Maria Viteri-Rojas. (2020). COMMUNICATION IN TIMES OF PANDEMIC, IMPACT IN ECUADORIAN EDUCATION. International Journal of Research GRANTHAALAYAH, 8(9), 345-350. https://doi.org/10.29121/granthaa layah.v8.i9.2020.1586

Received Date: 15 September 2020

Accepted Date: 30 September 2020

Keywords:

Technology Education

Internet

Student Teachers

\begin{abstract}
Currently, the COVID 19 pandemic has changed the world and all systems of society, bringing new demands on education and care in public service entities and the work of millions of people in the world. The new digital technologies have allowed the world to function in some way in this period of time, in all areas of society. In education a constant interaction is needed, between teachers and students, during teaching - learning. However, there are factors that affect this process, including internet accessibility, digital literacy, and the economic capacity of families to acquire an electronic device. In this sense, the Ecuadorian government must take actions to guarantee that students have access to the demands of the 21st century. The objective of this article is to analyze how the population is adapting to the new educational scheme, to visualize the urgent needs and give suggestions to solve them.
\end{abstract}

\section{INTRODUCTION}

Communication is a need for man to interact with other individuals of the same species, during the course of history this activity has been improved more and more, to better carry out the transmission of messages, conversations, and the exchange of ideas. With the new events caused by the COVID 19 pandemic, this process has been affected by the imposition of prevention measures, such as social distancing and teleworking, generating new communication trends. The coronavirus outbreak, SARS COV 2 has caused deaths and shock in all countries, since its rapid contagion has paralyzed all activities in the world, affecting industries, commerce, tourism, production, the economy, among other important aspects, for the development of countries, sowing panic in the population worldwide. (Ortiz J. 2020).

The so-called severe acute respiratory syndrome (SARS-CoV-2), (COVID-19, was identified for the first time in central China on December 1, 2019 in the city of Wuhan, capital of Hubei province. Evolution, development and form

(c) 2020 The Author(s). This is an open access article distributed under the terms of the Creative Commons Attribution License, which permits unrestricted use, distribution, and reproduction in any medium, provided the original author and source are credited. 
of contagion, caused the uncontrollable increase in cases, since it was transmitted from one person to another through the small droplets that are emitted when talking, sneezing, coughing, very contagious and aggressive and that spread rapidly. WHO recognized it as a global pandemic on March 11, 2020. The most affected countries are; the United States is the most affected country, Spain, Italy, Germany, the United Kingdom, France and Turkey and several Latin American countries such as Brazil, Argentina, Chile, Peru, among others (WHO 2020)

The Economic Commission for Latin America and the Caribbean (ECLAC) has stated that, even before facing the pandemic, the social situation in the region was deteriorating, due to the increase in poverty and extreme poverty rates, the persistence of inequalities and growing social discontent. In this context, the crisis will have significant negative effects on the different social sectors, in particular health and education, as well as on employment and poverty.

UNESCO has identified large gaps in educational outcomes, which are related to an unequal distribution of teachers, in general, and of better-qualified teachers, in particular, to the detriment of countries and regions with lower incomes and rural areas, which they tend to concentrate in addition to an indigenous and migrant population. A very important factor is also in relation to the training to take on this new challenge in the educational part.

In the educational field, a large part of the measures that the countries of the region have adopted in the face of the crisis, are related to the suspension of face-to-face classes, at all levels, and have originated emerging fields of action: distance learning modalities, using educational virtual formats and platforms, the support and mobilization of the personal teacher outside the educational communities, teleworking to protect the health and well-being of the students.

Traditional education in classrooms, schools, colleges and universities has been left behind, the perspective of face-to-face education in relation to distance education, in aspects such as the ability to learn, do and live experiences, has no point of comparison. With the new normality that has been imposed in the world by the authorities in charge of regulating this situation promoting the new virtual modality, everything is different and it is not yet known until when.

Currently, in many countries, the pandemic has been controlled and it is a matter of gradually returning to daily activities, which is why new infections have also appeared that have generated new emergencies and alarms. For this reason, the vast majority do it in digital form, in Ecuador this situation. In many cases, it has caused problems at all educational levels, due to the lack of internet coverage in some cases and in others due to lack of adequate facilities, especially in rural places, since not all regions of the country have the necessary infrastructure, To fulfill the assigned tasks, the lack of connectivity or equipment, on other occasions other problems arise, related to the lack of knowledge to work with electronic tools. Poverty and the loss of family jobs have also caused school dropouts, since being numerous families with 3 or 4 young people of study age, they do not have 4 computers to receive their classes each.

In the teaching field, there are factors such as ignorance of the existing methodological strategies to work virtual classes, with technological means, the lack of educational alternatives and adequate equipment to work from home, increase the effort and economic expense of the teacher who is also a parent of family. The teaching-learning process in the new context of the COVID 19 pandemic has forced everyone to evolve and adapt to this new scheme.

The COVID 19 pandemic has arrived, bringing new demands for education and care on public service entities and the work of millions of people around the world. It is known that the communication process implies that the human being builds, from the accumulation of previously acquired knowledge, the linguistic connections that allow constant interaction, the neural connections that condition immediate responses, teaching-learning processes, Conversations help interpersonal relationships and allow the development of the personal, confirming, personal self. Therefore, it is important to reflect on the way we communicate with other people; that is, our way of relating to those who live together (Maturana 2001).

\section{IN ECUADOR}

The global health and social economy crisis has forced governments to create new ways to address the needs of the population, with the first priority being to prevent new infections and deaths. To do this, first exit restriction measures were implemented and instructions were indicated to apply biosecurity measures through the use of masks, social distancing and the use of alcohol for hand disinfection. 
Msc. Alida Vallejo-López, Msc. Oswaldo Zavala Palacios, Ing. Cesar Noboa-Teran, Dra. Josefina Ramirez-Amaya, and Dra. Ana Maria Viteri-Rojas

In Ecuador, the government strengthened in a legal framework and coordinated by the Ministry of Public Health as the highest National Health Authority, faced the health problem to save all possible lives, on March 16, the president of Ecuador Lenin Moreno, declared the state of exception in which days the voluntary quarantine, the curfew, the prohibition of the arrival and departure by air and land and the vehicle restriction were established. A traffic light was established to indicate according to the colors red, yellow or green, in what situation each region is, based on the impact of registered contagion, in order to avoid the spread of the virus, from that moment the Government began to organize the actions against the pandemic, in the first instance Vice President Otto Sonneholzner, Minister María Paula Romo, with the team of Ministers supported by other police, army and sectional authorities assumed this task.

When the news of the pandemic became a worldwide trend, in all social networks and media, on the affected countries of Europe and America, the population looked for a way to face it, seeking information from the research carried out by scientists from all the world. With the confinement measures, the world found itself isolated in its homes and with diverse needs, both for food and for money and information, hence the need to start using technological means as an alternative to the crisis, assuming new forms of communicate.

Today most interactions are carried out by digital means, in this context new ways of carrying out activities were also implemented, by teleworking in all possible sectors. With these antecedents in the new reality, for the development of daily activities technology became indispensable, although it is true that technology had already gained ground in many aspects of society, now it is used in all human activities, Therefore, the accelerated increase in COVID 19 infections in the world has marked a milestone, when using desktop computers, tablets, mobile phones. It can be said that technology has engulfed the world in a new digital age for communication and connection of people.

In Ecuador, the government strengthened in a legal framework and coordinated by the Ministry of Public Health as the highest National Health Authority, faced the health problem to save all possible lives, on March 16, the president of Ecuador Lenin Moreno, declared the state of exception on which days the voluntary quarantine, the curfew, the prohibition of arrival and departure by air and land, and the vehicle restriction were established. A traffic light was installed to indicate, according to the colors red, yellow or green, in what situation each region is, depending on the impact of the registered contagion, in order to prevent the spread of the virus, from that moment the Government began. . To organize the actions against the pandemic, Vice President Otto Sonneholzner, Minister María Paula Romo, with the team of ministers supported by other police, military and sectional authorities took office.

When the news of the pandemic became a global trend, in all social networks and media, about the affected countries of Europe and America, the population looked for a way to face it, looking for information from research carried out by scientists from around the world. . With the confinement measures, the world found itself isolated in its homes and with diverse needs, both for food and for money and information, hence the need to start using technological means as an alternative to the crisis, assuming new forms of communication.

Today most interactions are carried out by digital means, in this context new ways of carrying out activities were also implemented, through teleworking in all possible sectors. With this antecedent in the new reality, for the development of daily activities, technology became fundamental, although it is true that technology had already gained ground in many aspects of society, it is now used in all human activities. Therefore, the accelerated increase in COVID 19 infections in the world has marked a milestone, when using desktop computers, tablets, mobile phones. It can be said that technology has immersed the world in a new digital age for communication and connection of people.

This new trend corresponds to a set of advances linked to three concepts: computing, telecommunications and audiovisual technologies. 21st century education focuses on learning to learn. New technologies stimulate the development of skills such as investigating, selecting, organizing and managing new information obtained from computer networks. It is essential that teachers and students know how to use these tools, so they need capacity and updating. Distance education is based on a pedagogical and didactic context, mediated between the teacher and the student, who are located in different spaces, stimulating autonomous learning and also collaboration between peers. E-learning is a process and a support for distance teaching - learning that takes place completely in a virtual way, taking advantage of the new information and communication media, in particular the internet (Ávalos, 2013, p.1516).

Ubiquitous mobile technologies have been incorporated for some time, and that is why what we call mobile learning or m-learning is emerging, which consists of using these electronic devices to learn. This is generating great 
expectations in the educational system and therefore interesting business initiatives and research projects are being carried out (Ávalos, 2013, p.15).

Regarding the offer of online courses for teachers, several of them have focused on the development and improvement of digital skills, in the context of virtual distance education. For example, in the Plurinational State of Bolivia the Digital Teacher Training course has been made available (Departmental Directorate of Education La Paz, 2020).

From the pedagogical point of view, virtuality implies the risk of loss of the face-to-face connection and can generate tensions due to overexposure of teachers and students, or due to difficulties in maintaining the pedagogical relationship. Especially in the initial educational levels, preschool and primary education, in which a coordinated work with parents or caregivers is required to accompany and mediate the processes of boys and girls. From the social point of view, the increase in unemployment and poverty (ECLAC, 2020b),

\section{CONCLUSIONS}

With the COVID 19 pandemic, the way of life of all human beings has changed, affecting all areas, social, economic, work and educational.

Job instability and socioeconomic problems influence the life of the general population, this situation generates emotional wear, overwhelm and stress in teachers.

Technological tools have become the most efficient means to carry out unavoidable educational activities, which is why teachers and students have been forced to use them.

There are problems of digital illiteracy, lack of access to the Internet, in many places, especially in rural areas and in developing countries.

The authorities should promote the development of training programs to strengthen skills that allow teachers, improve their classes and students to take advantage of digital media to learn better.

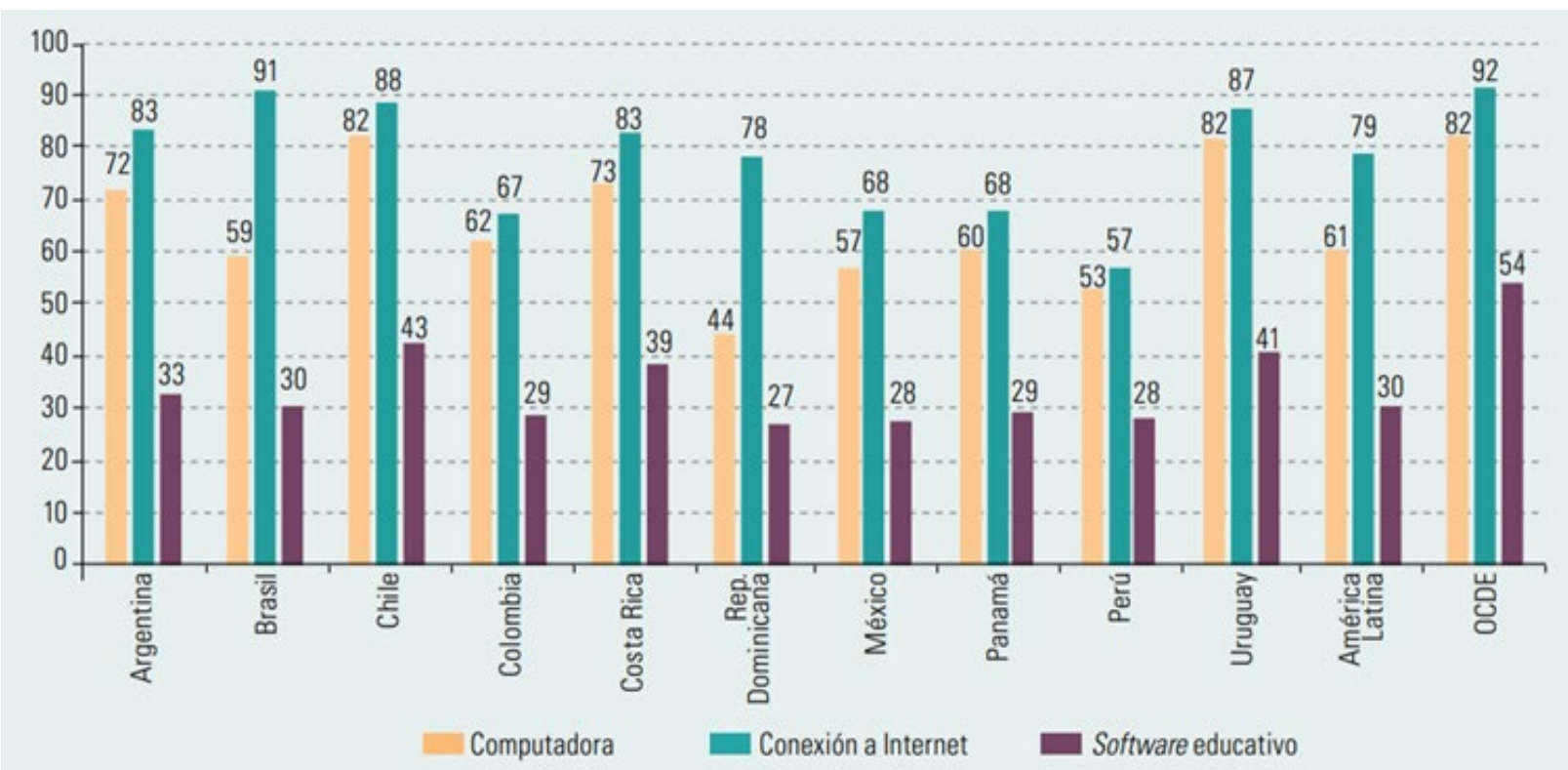

Fuente: Comisión Económica para América Latina y el Caribe (CEPAL), sobre la base de datos de Organización de Cooperación y Desarrollo Económicos (OCDE), Programa para la Evaluación Internacional de Estudiantes (PISA), 2018.

\section{PERCENTAGE OF STUDENTS WHO HAVE ACCESS TO DIGITAL TECHNOLOGY IN 10 COUNTRIES}

\section{SOURCES OF FUNDING}

This research received no specific grant from any funding agency in the public, commercial, or not-for-profit sectors. 
Msc. Alida Vallejo-López, Msc. Oswaldo Zavala Palacios, Ing. Cesar Noboa-Teran, Dra. Josefina Ramirez-Amaya, and Dra. Ana Maria Viteri-Rojas

\section{CONFLICT OF INTEREST}

The author have declared that no competing interests exist.

\section{ACKNOWLEDGMENT}

None.

\section{REFERENCES}

[1] Ávalos, M. (2013). ¿Cómo integrar las TIC en la escuela del siglo XXI? De Clementina a las las Tablets. Buenos Aires, Argentina: Editorial Biblos.

[2] Buitrago, A., Navarro, E. y García. A. (2015). La educación médiatica y los profesionales de la comunicación. Barcelona, España: Gedisa S.A.

[3] Cobo, C. y Moravec, J. (2011). Aprendizaje Invisible. Hacia una nueva ecología de la educación. Barcelona: Col-lecció Transmedia XXI. Laboratori de Mitjans Interactius / Publicacions i Edicions de la Universitat de Barcelona.

[4] Catuogno, A., y González, C. (2006). Educación Virtual en la escuela media. Guía parael docente. Buenos Aires, Argentina: Editorial Nueva Generación.

[5] Cepal 2020 Informe COVID 19 Cepal -Unesco. La educación en tiempos de pandemia COVID 19 https://repositorio.cepal.org/bitstream/handle/11362/45904/1/S2000510_es.pdf

[6] CEPAL (Comisión Económica para América Latina y el Caribe) (2020a), "América Latina y el Caribe ante la pandemia del COVID-19: efectos económicos y sociales", Informe Especial COVID-19, N 1, Santiago, 3 de abril. (2020b), "El desafío social en tiempos del COVID-19”, Informe Especial COVID-19, N 3, Santiago, 12 de mayo. (2020c), "Pandemia del COVID-19 llevará a la mayor contracción de la actividad económica en la historia de la región: caerá -5,3\% en 2020”, 21 de abril [en línea] https://www.cepal.org/es/comunicados/ pandemiacovid-19-llevara-la-mayor-contraccion-la-actividad-economica-la-historia-la.

[7] CEPAL/UNICEF (Comisión Económica para América Latina y el Caribe/Fondo de las Naciones Unidas para la Infancia) (2020), “La ciudad y los derechos de niñas, niños y adolescentes”, Desafíos, $\mathrm{N}^{\circ} 23$, Santiago, ene

[8] Litwin, E. (2009). Tecnologías Educativas en tiempo de internet.Buenos Aires,ntina: Amorrortu.

[9] Lozano, A.y Burgos, J. (2007). Tecnología educativa en un modelo de educación a distancia centrado en la persona. México: Limusa.

[10] MinEduc. (2012). Tecnologías de la Información y la Comunicación aplicadas a la 136 educación. Programa de Formación Contínua del Magisterio Fiscal. Recuperado el 29 de marzo de 2018 a partir de https://educacion.gob.ec/wpcontent/uploads/downloads/2013/03/SiProfe-TIC-aplicadas.pdf

[11] MinEduc. (2013). Tecnología para la Educación. Recuperado el 29 de marzo de 2018 a partir de https://educacion.gob.ec/tecnologia-para-la-educacion/

[12] MinEduc. (2017). Ecuador llevará internet a las aulas de clase. Recuperado el 30 de marzo de 2018 a partir de https://educacion.gob.ec/ecuador-llevara-internet-a-lasaulas-de-clase/

[13] Ministerio de Educación del Ecuador (2020), “El Ministerio de Educación abre el curso de autoaprendizaje ‘Mi Aula en Línea”' [en línea] https://educacion.gob.ec/el-ministerio-de-educacion-abre-el-cursodeautoaprendizaje-mi-aula-en-linea/ [fecha de consulta: 12 de junio de 2020].

[14] Pacheco, M. (2011). La influencia de las TICS en el proceso de enseñanza aprendizaje de los estudiantes de educación básica del colegio fiscal "17 de Septiembre". Universidad Estatal de Milagro. Recuperado el 30 de marzo de 2018 a partir de http://repositorio.unemi.edu.ec/handle/123456789/2139

[15] Peñaherrera, M. (2012). Uso de Tic en escuelas públicas de Ecuador: Análisis, reflexiones y valoraciones. EDUTEC. Revista Electrónica de Tecnología

[16] Educativa.40, Recuperado el 31 de marzo de 2018 a partir ehttp://edutec.rediris.es/Revelec2/Revelec40/uso_TIC_escuelas_publicas_Ecuador_analisis_reflexiones_val oraciones.html 
[17] Reina, G. (2012). Nuevas tecnologías aplicadas a la educación. La clase no finaliza en el aula. Buenos Aires, Argentina: Ugerman Editor.

[18] Romero, P., Altisen, C., Romero, J y Noro, J. (2017). La educación en su laberinto. Análisis y propuesta para una salida. Rosario, Argentina: Homo Sapiens Ediciones.

[19] UNESCO (Organización de las Naciones Unidas para la Educación, la Ciencia y la Cultura) (2020), "Nuevas publicaciones cubanas para enfrentar efectos de la COVID-19 sobre la educación”, Oficina de la UNESCO en La Habana [en línea] https://es.unesco.org/news/nuevas-publicaciones-cubanas-enfrentar-efectoscovid-19educacion [fecha de consulta: 12 de junio de 2020]. 